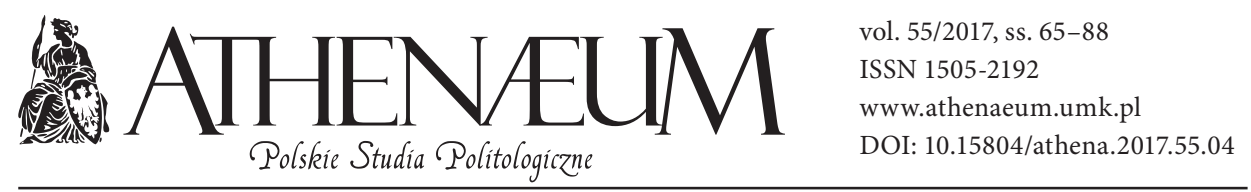

\title{
MIESZANY SYSTEM WYBORCZY - CZTERY WARIANTY DLA POLSKI
}

\author{
MIXED ELECTORAL SYSTEM: \\ FOUR VARIANTS FOR POLAND
}

Jarosław Flis*, Bartłomiej Michalak**

\begin{abstract}
ABSTRAKT
Artykuł przedstawia możliwe konsekwencje polityczne zastosowania mieszanego systemu wyborczego w wyborach do Sejmu RP. Zmiennymi zależnymi są: podział mandatów pomiędzy partie przy tej samej liczbie zdobywanych głosów, odchylenie wyników wyborczych od proporcjonalności oraz stopień koncentracji systemu partyjnego. Zmienną niezależną konkretne występujące na świecie i opisane w literaturze przedmiotu - typy systemów mieszanych. Testowi poddane zostały cztery warianty mieszanej ordynacji wyborczej, reprezentujące cztery podstawowe typy takich ordynacji. Symulacje przeprowadzono w oparciu o wyniki wyborów 2011 i 2015 roku oraz hipotetyczne wyniki dla wyborów 2019 roku. Poziom dysproporcjonalności systemu wyborczego oraz koncentracji systemu partyjnego został skonfrontowany z pomiarami tych parametrów wśród państw wykorzystujących tego systemy mieszane. Przedstawione wyniki pokazują, że ordynacje mieszane
\end{abstract}

The present paper deals with the possible political consequences of employing a mixed electoral system in the elections to Polish Sejm. The dependent variables are: distribution of seats amongst political parties which win the equal votes, deviation of election results from the proportionality and the degree of concentration of the party system. The independent variable are specific, described in the literature and actually existing types of mixed electoral systems. Four variants of electoral systems representing four basic types of such systems have been tested. Simulations have been conducted on the basis of 2011,2015, and hypothetical 2019 elections results. The degrees of an electoral system's disproportionality and of party system's concentration were juxtaposed with the measurements of these parameters in the countries which employ such mixed electoral systems. Presented results demonstrate that mixed electoral systems can lead to the whole spectrum of possible changes, depending on the employed type of the electoral system.

* Uniwersytet Jagielloński, Instytut Dziennikarstwa, Mediów i Komunikacji Społecznej.

** Uniwersytet Mikołaja Kopernika w Toruniu, Wydział Politologii i Studiów Międzynarodowych. 
mogą dać całe spektrum ewentualnych zmian, w zależności od ich konkretnego typu.

Słowa kluczowe: mieszane systemy wyborcze, wybory w Polsce, dysproporcjonalność wyborów, efektywna liczba partii parlamentarnych
Keywords: mixed electoral system, election in Poland, disproportionality, effective number of parliamentary parties

Mieszane systemy wyborcze tworzą najmłodszą klasę czy - jak nazywają to inni badacze - rodzinę systemów wyborczych. Termin mixed elctoral system w nauce o systemach wyborczych pojawił się już w latach 50. minionego stulecia za sprawą amerykańskich politologów Enida Lakemana i Jamesa Reilly Lamberta (Lakeman, Lambert, 1955, s. 96) opisujących właściwości ordynacji wyborczej do niemieckiego Parlamentu Związkowego. Jednak sami autorzy traktowali ten system jako jeden $\mathrm{z}$ wariantów reprezentacji proporcjonalnej (zob. Lakeman, Lambert, 1955, s. 15). Historycznie po raz pierwszy mieszany system wyborczy został wykorzystany na potrzeby wyborów do landtagu Królestwa Wirtembergii już w 1906 r. (Massicotte, Blais, 1999, s. 343, 360). Jednak do połowy lat 90. XX w. w zasadzie nikt nie traktował systemów mieszanych jako osobnej kategorii, rzadko też posługiwano się tą nazwą na ich określenie. W tym czasie niemiecki system wyborczy, będący przez większość okresu powojennego jedynym desygnatem systemu mieszanego, zyskał miano „spersonalizowanej reprezentacji proporcjonalnej" (zob. m.in. Kaase, 1984; Elklit, 1992, s. 200; Nohlen, 2004, s. 316; Colomer, 2004, s. 49; Taagepera, 2007, s. 40). Nazwa ta bardzo dobrze oddaje jego właściwości mechaniczne (orientacja personalna realizowana dzięki jednomandatowym okręgom wyborczym) i dominujące konsekwencje polityczne (wysoki poziom proporcjonalności wyników wyborów dzięki zastosowaniu mechanizmu proporcjonalnej alokacji wszystkich obsadzanych w wyborach mandatów). Z tego powodu szybko się przyjęła i jest do dziś stosowana w literaturze przedmiotu. Prowadzi to czasami do konfuzji terminologicznych, gdyż nadal nie wszyscy autorzy są skłonni zaliczać system niemiecki do kategorii systemów mieszanych (por. Raciborski, 2006, s. 38). Z drugiej strony niektórzy badacze zajmujący się tymi systemami to właśnie model niemiecki uważają za archetyp mieszanego systemu wyborczego w ogóle (tak m.in.: Ferrara, Herron, Nishikawa, 2005, s. 26; Norris, 1997, s. 300).

Celem tego artykułu jest przetestowanie, jakie konsekwencje polityczne przyniosłoby wprowadzenie ordynacji mieszanej w Polsce. Dzięki zastosowaniu 
symulacji możliwe będzie ich zidentyfikowanie w obszarze dwóch najważniejszych parametrów: przewidywanego odchylenia tych systemów od proporcjonalności oraz stopnia koncentracji systemu partyjnego na arenie parlamentarnej. Uzyskane w ten sposób wyniki pozwolą nie tylko zidentyfikować potencjalnych beneficjentów nowych rozwiązań, ale przede wszystkim porównać przewidywane efekty polityczne tych systemów $\mathrm{z}$ dotychczasowymi badaniami na ten temat prowadzonymi w odniesieniu do państw, które system mieszany wykorzystują lub wykorzystywały. Poza obszarem zainteresowania badania pozostają kwestie konstytucyjności ordynacji mieszanej, chociaż ocena poziomu ich empirycznej proporcjonalności może być jednym $\mathrm{z}$ ważkich argumentów w dyskusji na ten temat. Impulsem do prowadzonych analiz były także spekulacje medialne, dotyczące możliwości wprowadzenia takiego systemu jako sposobu zabezpieczenia stanu posiadania przez sejmową większość, wyłonioną w wyborach 2015 roku. Przeprowadzone symulacje mogą służyć jako test takich hipotez, które zwykle przedstawiane są bez oparcia w rzetelnych analizach. Są też pogłębieniem wstępnych szacunków, towarzyszących naukowym rozważaniom nad zmianą polskiej ordynacji wyborczej (Kamiński, 2016, s. 128-130).

\section{CHARAKTERYSTYKA MIESZANYCH SYSTEMÓW WYBORCZYCH}

Pod koniec lat 90. mieszane systemy wyborcze stały się bardzo popularne i zwróciły uwagę zarówno konstruktorów systemów wyborczych, politycznych decydentów, jak i politologów. Stało się to w wyniku ich dużej popularności w demokratyzujących się państwach, głównie z obszaru Europy Środkowo-Wschodniej. Liczba elekcji, jakie odbywały się pod rządami systemów mieszanych, wzrosła w tym czasie z $8 \%$ w latach 50 . do $18 \%$ na przełomie wieków (Bormann, Golder, 2013, s. 363). Szczegółowe badania historyczne wykazały, że po II wojnie światowej system mieszany był stosowany łącznie w 27 państwach ze wszystkich (poza Ameryką Północną) kontynentów. Najwięcej takich systemów wystąpiło w Europie. Było to 12 państw, z czego aż 8 z terenu Europy Środkowo-Wschodniej. Następne w kolejności obszary to: Azja - 7 państw, Afryka - 4, Ameryka Południowa - 3, Australia i Oceania - 1 (Michalak, 2013, s. 258-259). Obecnie wykorzystuje go ponad 20 państw świata.

Wzrost liczby państw stosujących systemy mieszane w różnych jego wariantach spowodował również zmianę w podejściu do konceptualizacji tego pojęcia. Przełomowe w tym kontekście okazały się analizy kanadyjskich politologów 
André Blaisa i Louisa Massicotte (Blais, Massicotte, 1996), którzy jako pierwsi przekonująco dowodzili, że mieszane systemy wyborcze tworzą osobną, jedną z głównych klas systemów wyborczych obok systemów większościowych i proporcjonalnych. Ich cechą charakterystyczną jest to, że pod względem mechanicznym są one dwuformułowe, tzn. są zbudowane $\mathrm{z}$ dwóch podsystemów obsługiwanych przez inne formuły (większościową i proporcjonalną) równocześnie i w ten sposób tworzących jedną całość. Takie rozumienie systemu mieszanego bardzo szybko zostało zaaprobowane przez kolejnych badaczy ${ }^{1}$.

W kolejnym swoim artykule (Massicotte, Blais, 1999), który do dziś stanowi jeden z najważniejszych i najczęściej cytowanych tekstów teoretycznych poświęconych systemom mieszanym, dokonali oni pełnej konceptualizacji tej kategorii, a w konsekwencji zaproponowali wyczerpującą definicję i sprzężoną z nią typologię mieszanych systemów wyborczych. Nie zakończyło to jednak sporów terminologicznych. Włoski politolog Giovanni Sartori twierdził np., że „prawdziwy system mieszany” to taki, który nie tylko jest mieszaniną dwóch formuł wyborczych (jak u Kanadyjczyków), ale jednocześnie generuje takie właśnie efekty polityczne (Sartori, 1997, s. 73-74). Z kolei niemiecki politolog Dieter Nohlen (2004, s. 119-132) zakwestionował odrębność kategorialną systemów mieszanych, twierdząc, że kluczowym kryterium różnicującym systemy wyborcze są ich rezultaty. W ten sposób każdy empirycznie istniejący system wyborczy, a więc również systemy mieszane, może być z powodzeniem przyporządkowany do systemu proporcjonalnego lub większościowego w zależności do tego, jaki cel polityczny realizuje w praktyce. $Z$ tego powodu system niemiecki jest dla Nohlena systemem całkowicie proporcjonalnym. Stanowisko Nohlena, choć logiczne i na gruncie przyjętych założeń dotyczących kryteriów klasyfikacji systemów wyborczych przekonujące, nie zyskało jednak propagatorów. Nie zniechęciło również innych badaczy do traktowania i badania systemów mieszanych jako osobnej kategorii systemów wyborczych ${ }^{2}$. Ważnym tropem wydaje się tu rozróżnienie stosowane przez większość badaczy - choć rzadko całkowicie otwarcie - na klasyfikację systemu „na wejściu” i „na wyjściu” (Nohlen, 2004, s. 161-162, Raciborski, 2006, s. 35). Idąc tym tropem, warte rozważenia byłoby zastosowanie innego określenia na rozróżnienie dwóch podstawowych formuł niż takie, które odwołuje się do zamierzonych efektów systemu (proporcjonalność i większo-

\footnotetext{
1 Przykładem: Norris, 1997, s. 300.

2 W polskiej literaturze przedmiotu poddane zostało również gruntownej krytyce: zob. Michalak, 2013, s. $128-131$.
} 
ściowość). Z takiego punktu widzenia pojęcia „kolejnośćc i „udział” wydają się określeniami bardziej precyzyjnymi (zob. Flis, 2014, s. 30-31). Problem ten nie jest jednak tematem tego artykułu, stąd w dalszej części używane będzie tradycyjne nazewnictwo.

Pozostawiając w tym miejscu kwestię sporów definicyjnych i precyzji pojęciowej nieco na uboczu, można się zgodzić na kompromisową "definicją minimalną" czy też swego rodzaju „rdzeń definicyjny” systemów mieszanych. Mimo braku jedności politologów co do precyzyjnego rozumienia tej kategorii badawczej, są oni zbieżni w podkreślaniu wieloformułowości tych systemów. Można zatem przyjąć, że „system wyborczy jest »mieszany« jeśli więcej niż jedna formuła jest stosowana do dystrybucji mandatów w organie ustawodawczym" (Ferrara i in., 2005, s. 17).

Istnieje powszechna zgoda w literaturze przedmiotu, że podstawowym kryterium różnicującym systemy mieszane jest sposób połączenia - czy też bardziej precyzyjnie - „zmieszania” ze sobą formuły większościowej i proporcjonalnej, które razem składają się na jeden system mieszany. Przyjmując za Nohlenem (2004, s. 121-122) założenie, że typologia systemów wyborczych powinna być zbudowana na kryterium najbardziej fundamentalnym w zakresie politycznych konsekwencji analizowanych systemów, prowadzi to do uznania, że systemy mieszane dzielą się na najwyższym poziomie systematycznym na te, których formuły wyborcze działają niezależnie od siebie, i te, które są ze sobą w jakiś sposób powiązane. Na tym założeniu zbudowana została pierwsza wyczerpująca klasyfikacja systemów mieszanych autorstwa Blaisa i Massicotte’a (1996). Podobnie postąpili - jeszcze bardziej precyzując, na czym polega rozłączność w działaniu formuł - amerykańscy politolodzy Matthew Soberg Shugart i Martin P. Wattenberg (2001, s. 9-11).

W ten sposób można wyodrębnić dwie najważniejsze i jednocześnie antytetyczne - choć wcale nie jedyne - podklasy systemów mieszanych. Po jednej stronie mamy systemy więc systemy, w których formuły wyborcze są w jakiś sposób zależne od siebie. Oznacza to, że liczba mandatów jakie dana partia uzyskuje z list partyjnych, jest powiązana z liczbą mandatów uzyskanych w subsystemie większościowym. Systemy takie nazywane są korekcyjnymi (Massicotte, Blais, 1999, s. 353), korygującymi (Sokół, 2007, s. 82), kompensacyjnymi (Gallagher, Mitchell, 2005; Taagepera, 2007, s. 591) lub po prostu mieszanymi systemami proporcjonalnymi (Farrell, 2001, s. 115; Shugart, Wattenberg, 2001, s. 13; Reynolds, Reilly, Ellis, 2005, s. 91; Ferrara i in., 2005, s. 38). Korekcyjność tych systemów ma wynikać $\mathrm{z}$ faktu, że formuła proporcjonalna niweluje deformacyjny charakter 
działającej równocześnie formuły większościowej. Mechanika tych systemów jest jednak taka, że to formuła proporcjonalna dokonuje alokacji wszystkich obsadzanych mandatów, a więc nie tylko tych, które formalnie są do niej przypisane. Mandaty obsadzane w jednomandatowych okręgach wyborczych przy zastosowaniu formuły większościowej w całości zawierają się w tym podziale. W ten sposób ich rola ogranicza się w zasadzie do funkcji „lokalizacyjnej”. Mandat jest przypisywany personalnie i terytorialnie w subsystemie większościowym, ale politycznie przydzielony został na podstawie głosów oddanych w części proporcjonalnej i przy wykorzystaniu algorytmu tej właśnie formuły. Oznacza to, że w systemach tego typu nie dokonuje się żadna kompensacja ani tym bardziej korekcja, bo to formuła proporcjonalna determinuje wyniki wyborów. Nie ma więc co kompensować. Możliwy jest za to proces odwrotny. W systemach, które - jak niemiecki czy nowozelandzki - dopuszczają istnienie mandatów nadwyżkowych stanowiących konsekwencję przyznania wszystkich mandatów obsadzonych w subsystemie większościowym ich zwycięzcom (nawet jeśli z ogólnego wyniku uzyskanego na podstawie podziału proporcjonalnego mandaty te nie powinny przypaść partiom, z których ci kandydaci się wywodzą), może dojść do niewielkiego odstępstwa od proporcjonalności. Jednak ze względu na relatywnie małą liczbę mandatów nadwyżkowych nie są to odchylenie duże. Badania empiryczne (patrz tabela 2) potwierdzają zresztą wysoką proporcjonalność tego typu systemów.

Po drugiej stronie mamy z kolei systemy, gdzie formuły wyborcza działają w całkowitej separacji funkcjonalnej. W literaturze te „niezależne” systemy mieszane nazywane są paralelnymi (Colomer, 2004, s. 550-551; Reynolds i in., 2005, s. 91), segmentowymi (Nohlen, 2004, s. 172), superpozycyjnymi (Massicotte, Blais, 1999, s. 349) czy - w przeciwieństwie do mieszanych systemów proporcjonalnych - mieszanymi systemami większościowymi (Farrell, 2001, s. 115; Shugart, Wattenberg, 2001, s. 13; Ferrara i in., 2005, s. 38). W takim systemie partia otrzymuje wszystkie przynależne jej mandaty, które zdobyli jej kandydaci bezpośrednio w subsystemie większościowym i dodaje je do tych, które uzyskała za pośrednictwem list partyjnych w części proporcjonalnej.

Jednak w systemach mieszanych zależnych od siebie powiązania mogą wystąpić nie tylko w zakresie dystrybucji mandatów, ale również oddanych głosów. W takim przypadku głosy uzyskiwane w jednym subsystemie nie są jedynymi, które decydują o podziale mandatów w tej części. Występuje tutaj bowiem transfer głosów pomiędzy obydwoma substytutami, przy czym może on mieć zarówno charakter pozytywny (jak na Węgrzech), jak i negatywny (jak 
we Włoszech)3 ${ }^{3}$. Biorać pod uwagę korygujący charkter tego transferu, to właśnie dla tej grupy systemów adekwatniejszą nazwą byłoby określenie „systemy korekcyjne".

Analitycznie wyodrębniając i jednocześnie krzyżując ze sobą fakt powiązania występującego pomiędzy dwoma formułami wyborczymi składającymi się na system mieszany - tak w zakresie dystrybucji mandatów (liczba mandatów zdobyta przez partię jest zdeterminowana przede wszystkim przez działanie formuły proporcjonalnej), jak i transferu głosów pomiędzy subsystemami (głosy z jednego subsystemu mogą przeniknąć, a tym samym wpływać na wyniki drugiego) - Shugart i Wattenberg (2001, s. 15-17) zaproponowali wyczerpująca i kompletną klasyfikację systemów mieszanych. Umożliwia ona przyporządkowanie do jednej z tak wyodrębnionych klas każdego empirycznego odpowiednika systemu mieszanego (zob. tabela 1 ).

Tabela 1. Klasyfikacja mieszanych systemów wyborczych i przykłady państw, które je stosują lub stosowały po 1945 r.

\begin{tabular}{|c|l|l|}
\hline $\begin{array}{c}\text { Powiązanie dystrybucji } \\
\text { mandatów między } \\
\text { formułami }\end{array}$ & \multicolumn{2}{|c|}{ Transfer głosów między formułami } \\
\cline { 2 - 3 } & \multicolumn{1}{|c|}{ Nie } & \multicolumn{1}{|c|}{ Tak } \\
\hline \multirow{2}{*}{ Nie } & $\begin{array}{l}\text { Systemy paralelne (segmentowe): } \\
\text { Andora, Albania, Armenia, Azer- } \\
\text { bejdżan, Bułgaria, Chorwacja, } \\
\text { Gruzja, Gwinea, Jordania, Korea Pd., } \\
\text { Litwa, Meksyk, Macedonia, Monako, } \\
\text { Rosja, Seszele, Tajlandia, Ukraina, } \\
\text { Wenezuela }\end{array}$ & $\begin{array}{l}\text { Systemy korekcyjne (transferu } \\
\text { głosów): } \\
\text { Japonia, Węgry, Włochy }\end{array}$ \\
\hline \multirow{2}{*}{ Tak } & $\begin{array}{l}\text { Mieszane systemy proporcjonalne: } \\
\text { Boliwia, Lesotho, Niemcy, Nowa } \\
\text { Zelandia, Wenezuela }\end{array}$ & $\begin{array}{l}\text { Systemy kombinowane*: } \\
\text { Badenia-Wirtembergia, Bawaria }\end{array}$ \\
\hline
\end{tabular}

* Systemy te nie występują w klasyfikacji Shugarta i Wattenberga.

Źródło: opracowanie własne.

${ }^{3} \mathrm{Na}$ Węgrzech głosy oddane na kandydatów, którzy nie zdobyli mandatów w okręgach jednomandatowych, są dodawane do list partyjnych komitetów, które takich kandydatów zgłosiły. Z kolei we Włoszech działał mechanizm odwrotny. Liczba głosów oddanych na listy partyjne jest pomniejszana o głosy kandydatów stowarzyszonych z tymi listami, którzy zdobyli mandaty bezpośrednio w segmencie większościowym. 
Jak już zostało wskazane powyżej, najdłużej funkcjonującym na świecie i najlepiej znanym system mieszanym jest system funkcjonujący w Niemczech od 1949 r. (w obecnym kształcie od 2009 r.). Wyborca ma do swojej dyspozycji dwa głosy. Oddzielnie głosuje na zamkniętą listę w subsystemie proporcjonalnym na szczeblu landu i oddzielnie na kandydatów w terytorialnych okręgach jednomandatowych. Pula mandatów pomiędzy obydwa subsystemami jest formalnie podzielona po równo (po 299 mandatów).W części większościowej wykorzystuje się formułę większości względnej, a w części proporcjonalnej system list zamkniętych z klauzulą zaporową na poziomie 5\% (lub alternatywnie 3 mandatów bezpośrednio zdobytych w jednomandatowych okręgach wyborczych). Kluczową kwestią jest to, że zasadniczy podział mandatów odbywa się tylko na podstawie głosu proporcjonalnego (partyjnego). Jeżeli bowiem $\mathrm{z}$ okręgów jednomandatowych do Bundestagu nie wszedł żaden poseł niezależny (co jest regułą w praktyce politycznej Niemiec), to za pomocą metody Sainte-Laguë-Schepersa (wcześniej Hare’a-Niemeyera) dzieli się wszystkie 598 mandatów proporcjonalnie. W przeciwnym przypadku liczba mandatów podlegających proporcjonalnej dystrybucji ulega zmniejszeniu o liczbę mandatów obsadzonych w subsystemie większościowym przez kandydatów niezależnych. Mandaty przydzielone poszczególnym partiom na podstawie tej procedury dzieli się proporcjonalnie do liczby uzyskanych głosów pomiędzy poszczególne listy krajowe (landowe) danej partii. W ten sposób mandaty przypisywane są do konkretnych okręgów wyborczych. Następnie są obsadzane przez kandydatów zgłoszonych przez te partie w tych okręgach według kolejności, w jakiej umieszczeni zostali na listach krajowych, z tym zastrzeżeniem, że od liczby mandatów przynależnych danej partii w danym landzie odejmuje się te mandaty, które jej kandydaci zdobyli już w okręgach jednomandatowych znajdujących się na obszarze tego landu. W przypadku gdy danej partii, w wyniku podziału proporcjonalnego, przyznano w danym landzie mniej miejsc, niż uzyskała ona bezpośrednio w segmencie większościowym, nie obsadza ona żadnych mandatów z list partyjnych, ale zachowuje „nadmiarowe” mandaty $z$ okręgów jednomandatowych. W takiej sytuacji łączna liczba posłów do Bundestagu ulega zwiększeniu o mandaty nadwyżkowe (Haman, 2003, s. 191; Nohlen, 2004, s. 318). Ta niekorzystna właściwość systemu niemieckiego jest konsekwencją zastosowania algorytmu podziału mandatów odwołującego się do metody z kwotą a priori. Zastosowanie metody z kwotą a posteriori (dzielnikową) rozwiązuje problem mandatów nadwyżkowych. Przykładem jest system wyborczy Boliwii. Tam, jeśli jakaś partia zdobędzie więcej miejsc w parlamencie w subsystemie większościowym, niż wynika to z podziału proporcjonalnego, 
wtedy jej kandydaci zatrzymują uzyskane bezpośrednio mandaty. Wytworzona nadwyżka zostaje zredukowana w ten sposób, że o taką samą liczbę zmniejsza się pula mandatów obsadzanych proporcjonalnie, a mandaty tracą te partie, których ilorazy uzyskane przy wykorzystaniu metody d'Hondta są najmniejsze (Mayorga, 2001, s. 203).

Osobną podkategorię zależnych systemów mieszanych stanowią systemy, które ze względu na fakt połączenia zarówno dystrybucji mandatów, jak i transferu głosów można określić mianem systemów kombinowanych. Przypadki wykorzystywania tego podwójnego powiązania $\mathrm{w}$ działaniu formuł wyborczych są dość rzadkie. Jak do tej pory żadne państwo nie zaadaptowało tego rozwiązania w wyborach ogólnokrajowych. Na szczeblu regionalnym stosowane jest natomiast w niemieckich landach: Badenii-Wirtembergii i Bawarii. W Badenii-Wirtembergii w wyborach do 150-osobowego landatgu wyborca posiada tylko jedne głos, który oddaje na kandydata w jednym z 70 okręgów terytorialnych. Te głosy liczą się dwa razy. Po raz pierwszy, jako głosy oddane bezpośrednio na kandydatów w swoich okręgach w subsystemie większościowym. Po raz drugi, jako głosy na partie zgłaszające tych kandydatów. Na podstawie tego drugiego „liczenia” ustala jest liczba mandatów przypadających danej partii proporcjonalnie do liczby zdobytych przez nią w ten sposób głosów w czterech okręgach wyższego rzędu (Regierungsbezirk). Oznacza to, że liczba mandatów, jaką uzyskuje w wyborach każda partia, jest zdeterminowana działaniem formuły proporcjonalnej. Następnie mandaty obejmują personalnie zwycięzcy w okręgach terytorialnych. Jeśli liczba zwycięskich kandydatów jest mniejsza niż liczba należnych jej mandatów, kolejne miejsca w parlamencie obejmują ci spośród jej niewybranych do tej pory kandydatów, którzy uzyskali największą liczbę głosów spośród wszystkich w swojej partii. W ten sposób do części okręgów terytorialnych trafiają kolejne mandaty, a obejmują je kandydaci, którzy wcześniej nie zdobyli w nich mandatów. Ostateczna wielkość niektórych okręgów wynosi zatem więcej niż jeden mandat i może zwiększyć się nawet do trzech (Scheble, 2015). Z kolei w systemie bawarskim proporcjonalny podział mandatów odbywa się na podstawie sumy głosów oddanych na kandydatów w okręgach jednomandatowych oraz tych oddanych na listy. Mandaty zdobyte w okręgach jednomandatowych wliczane są do mandatów należnych partii tak jak w systemie ogólnoniemieckim.

Węgry stanowią z kolei przykład systemu korekcyjnego podobnie jak włoski wariant ordynacji mieszanej stosowany w latach 1993-2005 (Farrell, 2011, s. 119-117). Systemy te można również określić ze względu na ich specyfikę 
systemami transferu głosów (Michalak, 2013, s. 185, 242-257) ze względu na fakt, że subsystemy większościowy i proporcjonalny są ze sobą połączone właśnie poprzez transfer głosów z tego pierwszego do drugiego. W obecnym kształcie system węgierski funkcjonuje od 2011 r. Również w tym systemie wyborca ma do dyspozycji dwa głosy. Do transformacji głosów na mandaty wykorzystywana jest metoda d'Hondta. Istotą tego systemu jest to, że głosy „stracone” w jednomandatowych okręgach wyborczych, tzn. takie, które nie zostały wykorzystane do zdobycia mandatu, zostaną doliczone (przetransferowane) do głosów oddanych na listę partii politycznej danego kandydata w części proporcjonalnej. Dotyczy to zarówno kandydatów, którzy nie zdobyli mandatu, jak również zwycięzców. W tym drugim przypadku od ogólnej liczby głosów zdobytych przez takiego kandydata odejmowany będzie wynik osoby drugiej w kolejności powiększony o jeden. Uzyskane w ten sposób głosy „nadwyżkowe” zostaną doliczone do listy krajowej partii tego kandydata w subsystemie proporcjonalnym (Álvarez-Rivera, 2012).

Historycznie rzecz biorąc, najstarszymi mieszanymi systemami wyborczymi były systemy z subsystemami funkcjonującymi niezależnie od siebie. Taki właśnie charakter miał system zastosowany na początku XX w. w Wirtembergii. I choć szybko wyrosła mu konkurencja, to jednak system paralelny dominuje, jeśli chodzi o liczbę stosujących go państw. Szczególną popularność i prawdziwy rozkwit systemów tego typu nagapił w latach 90. minionego stulecia w państwach byłego bloku komunistycznego. Do tej pory w sumie stosowało go 21 państw spośród 29, które kiedykolwiek wykorzystywały jakiś wariant ordynacji mieszanej. Jest to zatem $\mathrm{z}$ całą pewnością typ najpopularniejszy. Popularność ta jest wynikiem względnej prostoty takiego systemu. Fakt, że obydwa współtworzące go subsystemy pozostają ze sobą w separacji, a każda $\mathrm{z}$ formuł wyborczych obsadza mandaty niezależnie od drugiej, czynią je systemami łatwymi do stosowania. Mowa tutaj oczywiście o separacji funkcjonalnej, polegającej na tym, że każdy $\mathrm{z}$ segmentów dysponuje własnym, odrębnym i niepowiązanym $\mathrm{z}$ drugim segmentem mechanizmem wyborczym równolegle przetwarzającym głosy w mandaty. Z tego właśnie powodu przez wielu badaczy są one uważane właśnie za truly mixed system (Sartori, 1997, s. 73; Nohlen, 2004, s. 131), bo w przeciwieństwie do pozostałych wariantów systemów mieszanych ich wyniki nie są konsekwencją dominacji formuły proporcjonalnej.

Modelowym wręcz przykładem takiej ordynacji jest Rosja. Po raz pierwszy system mieszany został tam przyjęty w 1993 r. i obowiązywał do 2005 r. W 2014 r. powrócił, zastępując system proporcjonalny. W tym systemie proporcja man- 
datów pomiędzy segmentem większościowym i proporcjonalnym kształtuje się po równo. W każdym z nich obsadza się oddzielnie 225 mandatów. Wyborca ma do dyspozycji dwa głosy. Jeden oddaje bezpośrednio na kandydata zgłoszonego w jednomandatowym okręgu wyborczym, a drugi na zamkniętą, federalną listę partyjną $\mathrm{w}$ subsystemie proporcjonalnym. $\mathrm{W}$ okręgu jednomandatowym zwycięża ten kandydat, który zdobywa największą liczbę głosów w okręgu. Do udziału w podziale mandatów z części proporcjonalnej konieczne jest przełamanie 5\% klauzuli zaporowej. Mandaty dystrybuowane są pomiędzy listy dzielone z kolei w oparciu o metodą Hare'a-Niemeyera (Moser, Thames, 2001, s. 257-258). Rozwiązanie to jest najprostszym z możliwych, istnieją jednak w praktyce państwa, gdzie poszczególne parametry poszczególnych subsystemów przybierają inne wartości. Na Litwie przykładowo stosuje się formułę większości bezwzględnej i dwie tury w części większościowej. W Korei Południowej czy na Tajwanie zdecydowanie dominuje segment większościowy, gdyż aż 80\% mandatów obsadzanych jest w subsystemie większościowym. Na Tajwanie zamiast jednomandatowych funkcjonują wielomandatowe okręgi wyborcze w części większościowej. Różnie też kształtuje się wysokość progów zaporowych w części proporcjonalnej, a Tajlandia i Wenezuela wykorzystywały metodę d'Hondta do podziału głosów na mandaty. Wszystkie te różnice wynikające $\mathrm{z}$ odmiennych kontekstów politycznych danych państw. Co oczywiste, wpływają one na ostateczny rezultat wyborów i generowane konsekwencje polityczne. Nie zmieniają jednak zasadniczej istoty mieszanych systemów paralelnych wynikającej z funkcjonalnej separacji składających się na nie podsystemów.

Tabela 2. Średni poziom dysproporcjonalności i efektywna liczba partii parlamentarnych w mieszanych systemach wyborczych

\begin{tabular}{|c|c|c|}
\hline Typ systemu & Gh & ENP \\
\hline mieszany proporcjonalny & 3,22 & 3,50 \\
\hline korekcyjny (transferu głosów) & 12,67 & 3,01 \\
\hline paralelny & 10,68 & 3,34 \\
\hline
\end{tabular}

Objaśnienia: Gh - wskaźnik dysproporcjonalności (Gallagher, 1991); ENP - efektywna liczba partii parlamentarnych (Laakso, Taagepera, 1979).

Źródło: opracowanie własne na podstawie Michalak, 2013, s. 317, 376. 


\section{PRZEWIDYWANE KONSEKWENCJE WPROWADZENIA ORDYNACJI MIESZANEJ W POLSCE}

Badania porównawcze w obrębie państw stosujących mieszane systemy wyborcze dotyczyły trzech z wyżej opisanych typów. Systemy kombinowane stosowane są - jak wspomniano - wyłącznie na poziomie regionalnym. Stąd też brak jest materiału do porównań, które prowadzone są na podstawie wyników wyborów ogólnokrajowych. Jak pokazano w tabeli 2 , każdy z takich systemów wywołuje nieco inne konsekwencje polityczne. Dlatego rozważając możliwość wprowadzenia ordynacji mieszanej w Polsce, należy dokładnie przeanalizować działanie każdego z tych typów w praktyce. Realizacja tego celu będzie możliwa dzięki zastosowaniu symulacji wyników wyborczych pod rządami każdego z typów systemu mieszanego. Na jej potrzeby założyliśmy, że głosy z wyborów 2011 i 2015 r. przeliczano w taki sposób, jakby każdy z wyborców zagłosował identycznie wskazując kandydatów w okręgach jednomandatowych i wybierając listy partyjne. Założenie o nierozdzielaniu głosów przez wyborców jest oczywiście uproszczeniem. Za jego przyjęciem przemawia jednak wiele argumentów. Po pierwsze, badania porównawcze poświęcone zjawisku rozdzielania głosów przez wyborców w systemach mieszanych (split voting; ticket splitting) pokazują, że liczba wyborców rozdzielających swoje głosy jest nadal mniejsza niż głosujących spójnie ${ }^{4}$. Po drugie, jako estymację tego, jak mogliby się zachować Polacy w warunkach systemu $\mathrm{z}$ wielogłosem, można potraktować dotychczasowe strategie podczas głosowania w wyborach do Sejmu RP i do Senatu RP traktowanych łącznie jako wybory tego samego parlamentu. Empiryczne badania zachowań elektoratu (Flis, 2014, s. 65-69; Michalak, 2016, s. 76) pokazują, że w tych wyborach Polacy w zdecydowanej większości głosują spójnie politycznie (tzn. głosują na kandydatów z tych samych ugrupowań do Sejmu i do Senatu). Jeśli zaś rozdzielają swoje głosy i wskazują w wyborach senackich kandydatów innych partii niż w wyborach sejmowych, to częściej są to kandydaci mniejszych ugrupowań. Jest to zatem mechanizm dokładnie odwrotny od tego, który występuje w przypadku wyborów niemieckich, szkockich czy nowozelandzkich. Stąd

4 Dla przykładu w wyborach do niemieckiego Bundestagu w 1953 r. tylko $10 \%$ głosujących je rozdzieliło. W 1961 r. wartość ta spadła do 4,4\%, choć w latach 70. zaczęła ponownie rosnąć, osiągając 16,2\% w 1990 r. (Schoen, 1999, s. 474). Z kolei w Szkocji i Walii podczas pierwszych wyborów przeprowadzonych w oparciu o system mieszany w 1999 r. było takich głosów ok. 20\%. W analogicznej sytuacji w Nowej Zelandii w 1996 r. było to 37\% i 35\% w 1999 r. (Gschwend, van der Kolk, 2006, s. 164). 
wydaje się akceptowalne założenie, że przypadki podziału głosów nie byłyby wystarczająco częste i systematyczne, by jakościowo zmienić wyniki wyborów w stosunku do modelu spójnego głosowania. Wreszcie ostatni argument wiąże się z oszczędnością dodatkowych założeń. Każda symulacja pozwalająca oszacować spodziewane odchylenia w głosowaniu na obu poziomach systemu byłaby nieuchronnie zagrożona błędami przy przyjmowanych założeniach. Przyjęcie jednego, najprostszego założenia pozwala unikać tego typu błędów. Takie symulacje można zaś traktować także jako punkt wyjścia do dalszych analiz, w których zastosowane zostaną bardziej złożone modele - np. wykorzystujące wyniki głosowania w wyborach senackich.

W symulacji założono obowiązywanie dotychczasowej 5\% klauzuli zaporowej, która jest zresztą standardem wśród państw stosujących systemy mieszane. Dla wszystkich systemów i wyborów został przyjęty jeden podział na 230 jednomandatowych okręgów wyborczych, o stosunkowo dużym zróżnicowaniu co do rozmiaru poszczególnych okręgów, przy możliwym zachowaniu ich zgodności z podziałem administracyjnym.

Pierwszy z testowanych systemów to proporcjonalny system mieszany, który w dalszej części dla uproszczenia będzie nazywany „niemieckim”. Zastosowanie systemu na wzór ordynacji niemieckiej wymaga, aby 460 mandatów było dzielone proporcjonalnie na podstawie tzw. głosu partyjnego w poszczególnych województwach. Zwycięzca w każdym z jednomandatowych okręgów otrzymuje mandat. Mandaty zdobywane przez poszczególne partie bezpośrednio w okręgach jednomandatowych byłyby z kolei wliczane do puli mandatów należnych poszczególnym ugrupowaniom. Oczekiwana maksymalna proporcjonalność wyborów w tym systemie została podkreślona wyborem województwa jako jednostki, w której następuje rozliczenie mandatów. Takie rozwiązanie było zastosowane w zgłaszanych dotąd w Sejmie projektach podobnej ordynacji.

Jako przykład kolejnego typu - ordynacji kombinowanej - została przyjęta ordynacja zwana dalej „,badeńską”, wzorowana na systemie z tego właśnie landu. Przyjęto w niej podział kraju na dotychczasowe 41 okręgów z zastosowaniem systemu d'Hondta. System ten również wykorzystuje 230 (pod)okręgów. Z kolei w tym systemie nazwa ,jednomandatowe" wydaje się umiarkowanie adekwatna, skoro w takim okręgu może zostać przyznanych kilka mandatów. Dalej jednak jedna partia może w okręgu zdobyć tylko jeden mandat. Pomimo pozostawienia znanych z obecnego systemu 41 okręgów wyborczych nieznacznej zmianie uległa liczba rozdzielanych w części z nich mandatów. Ponieważ system zakłada, że proporcje mandatów zdobywanych bezpośrednio do ogółu rozdzielanych są 
stałe, stąd liczbę mandatów w okręgach skorygowano tak, by zawsze była to liczba parzysta. W ten sposób mandaty zdobywane bezpośrednio zawsze stanowią połowę mandatów rozdzielanych w okręgu. System ten był tym samym możliwie najbardziej zbliżony do obecnego systemu wyborczego.

Kolejny testowany typ to system korekcyjny. On również zakłada głosowanie w 230 okręgach jednomandatowych. Inaczej niż w modelowym rozwiązaniu węgierskim zakładamy możliwość oddania tylko jednego głosu przez wyborcę. Pozostałe 230 mandatów rozdzielanych jest proporcjonalnie w skali kraju, jednak nie na podstawie sumy głosów oddawanych na poszczególnych kandydatów w okręgach jednomandatowych. Do puli głosów, na podstawie których rozdzielane są te 230 mandaty, wchodzą wszystkie głosy oddane na przegranych kandydatów oraz te głosy oddane na zwycięskich kandydatów, które stanowią nadwyżkę nad drugim najlepszym kandydatem (najsilniejszym konkurentem) w danym okręgu wyborczym (mechanizm transferu głosów). Przykładowo, jeśli zwycięzca zdobywa w swoim okręgu 50000 głosów, a najlepszy z przegranych kandydatów otrzymał ich 30 000, to 20000 głosów oddanych na zwycięskiego kandydata wchodzi do puli ogólnokrajowej, tak jak 30000 głosów oddanych na jego najgroźniejszego rywala. System ten dalej będzie skrótowo określany jako „węgierski”.

Ostatni z analizowanych wariantów to system paralelny. Zastosowanie modelu paralelnego upraszcza sprawę podziału mandatów ze względu na rozłączność funkcjonalną obydwu formuł wyborczych. Oznacza to, że 230 mandaty są dzielone w jednomandatowych okręgach wyborczych, a kolejna połowa proporcjonalnie w 16 województwach, ale już bez jakiegokolwiek związku z tym, kto zdobył mandaty bezpośrednio w części większościowej. To rozwiązanie będzie dalej określane skrótowym mianem systemu „rosyjskiego”.

Konsekwencje polityczne zastosowania tych systemów w Polsce pokazują poniższe wykresy i tabele.

Wyniki symulacji dla ordynacji „niemieckiej” potwierdzają to, co pokazują badania przeprowadzone w państwach stosujących ten model (patrz tabela 2). Jest ona bardziej proporcjonalna niż obecny polski system. W takim rozwiązaniu zwycięska Platforma Obywatelska traci 10 mandatów, a o 9 mniej przypada Prawu i Sprawiedliwości. Jeśli chodzi o mniejsze partie, to wszystkie zyskują, przy czym wyraźnie więcej zyskuje PSL i SLD niż Ruch Palikota.

Przejście w rozliczeniu mandatów na 41 okręgów - w wariancie „badeńskim” ordynacji - daje nieomal identyczne wyniki, jakie przyniosła obecna ordynacja. 


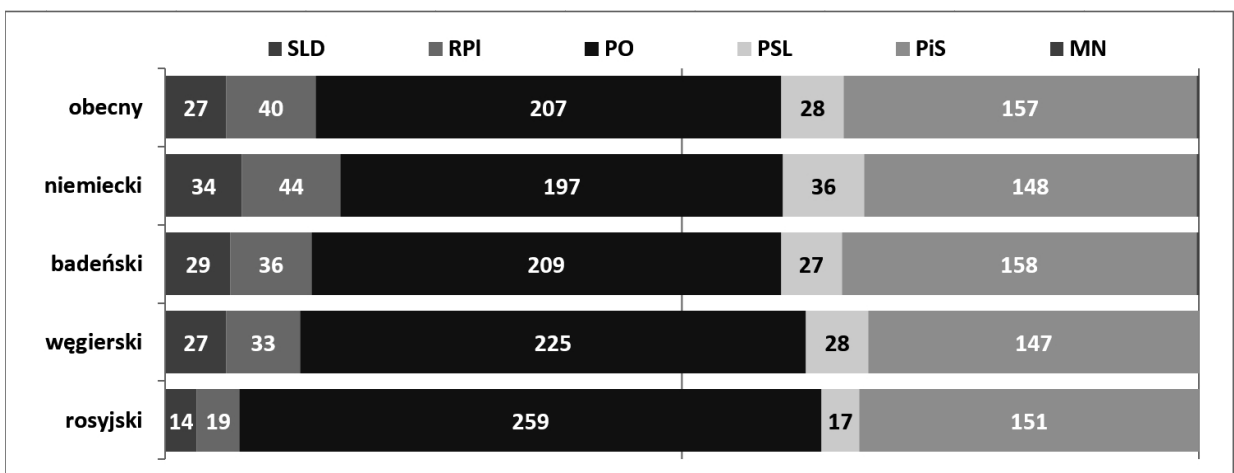

Wykres 1. Porównanie podziału mandatów pomiędzy obecnym systemem a symulowanymi wariantami systemów mieszanych na podstawie wyników głosowania z 2011 r.

Źródło: opracowanie własne.

To właśnie liczba okręgów, w których rozdzielane są mandaty dla partii, przesądza o pojawieniu się nagrody dla zwycięskiego ugrupowania, jak również dla drugiej partii, jeśli jest odpowiednio dużego rozmiaru.

Zastosowanie systemu „węgierskiego” zwiększa nagrodę dla zwycięskiej partii o 20 dodatkowych mandatów. Największą częścią tego zysku jest koszt, jaki ponosi Prawo i Sprawiedliwość, które traci 10 mandatów. Drugim stratnym jest Ruch Palikota. Z kolei wyniki PSL i SLD pozostają bez zmian względem obecnego systemu. Wydaje się, że partie o poparciu w okolicach $8 \%$ są w podobnym stopniu poszkodowane zarówno przez obecny system, jak i przez system „węgierski”. Pomimo tej nagrody Platforma Obywatelska ze swoim słabszym, wyjściowym wynikiem, związanym z mniejszą liczbą zmarnowanych głosów w wyborach 2011 r., nie zdobywa samodzielnej większości. Jest jednak tego dosyć bliska ze swoimi 225 mandatami. Jednocześnie bez najmniejszego problemu, podobnie jak miało to miejsce w rzeczywistości, tworzy koalicję z PSL. Z kolei PiS pozbawiane jest tej nagrody, którą zapewnia mu obecny system.

Wreszcie system „rosyjski” daje największą nagrodę zwycięzcy i zapewnia Platformie Obywatelskiej samodzielne rządy przy 259 mandatach. Mniejsze ugrupowania wchodzą do Sejmu uszczuplone o prawie połowę mandatów w stosunku do historycznego wyniku wyborów. Dodatkowo poszkodowane jest też Prawo i Sprawiedliwość, które traci 6 mandatów. 
Tabela 3. Poziom dysproporcjonalności i efektywna liczba partii parlamentarnych dla prawdziwych i symulowanych wyników wyborów w 2011 r.

\begin{tabular}{|c|c|c|}
\hline Typ systemu & Gh & ENP \\
\hline obecny & 5,95 & 3,00 \\
\hline niemiecki & 3,61 & 3,25 \\
\hline badeński & 6,33 & 2,96 \\
\hline węgierski & 7,88 & 2,83 \\
\hline rosyjski & 13,99 & 2,33 \\
\hline
\end{tabular}

Objaśnienia: Gh - wskaźnik dysproporcjonalności (Gallagher, 1991); ENP- efektywna liczba partii parlamentarnych (Laakso, Taagepera, 1979).

Źródło: opracowanie własne.

Ogólnie można przyjąć, że żadna z tych zmian, nawet jeśli prowadzi do wyraźnego przesunięcia mandatów, nie podważa wyniku i nie daje żadnych perspektyw na powiększenie stanu posiadania przez Prawo i Sprawiedliwość, gdyby poparcie dla poszczególnych sił wróciło do stanu z $2011 \mathrm{r}$.

Kolejnym testem było porównanie wyników wyborów 2015 r., w przypadku przeliczenia ich za pomocą trzech różnych systemów mieszanych. Wyniki wszystkich zmian pokazano na kolejnym wykresie.

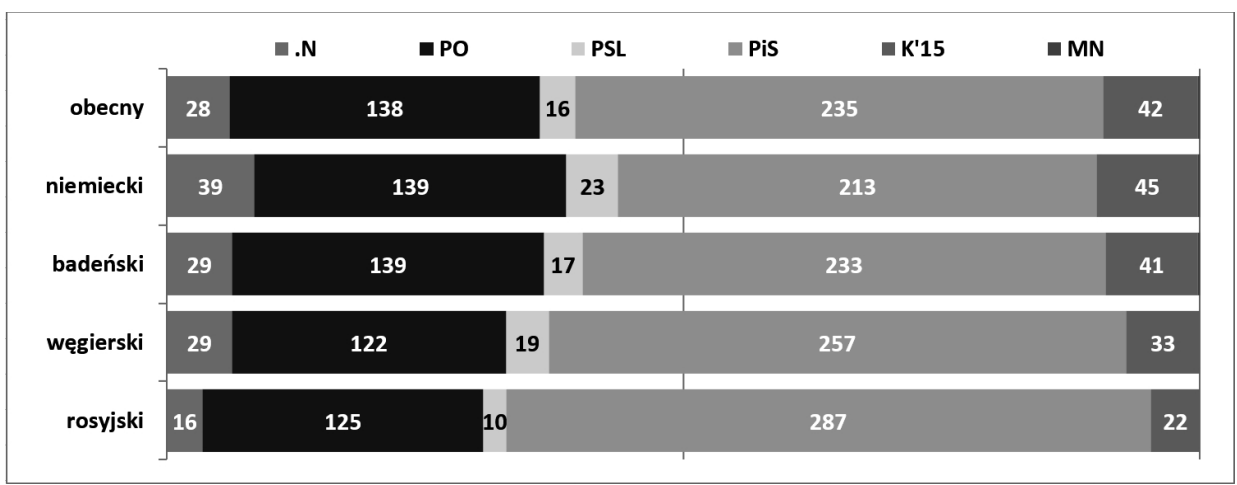

Wykres 2. Porównanie podziału mandatów pomiędzy obecnym systemem a symulowanymi wariantami systemów mieszanych na podstawie wyników głosowania z 2015 r.

Źródło: opracowanie własne. 
Przeliczenie wyników z 2015 r. w systemie „niemieckim” odbiera samodzielną większość Prawu i Sprawiedliwości, które otrzymuje o 22 mandaty mniej. Zyski w mandatach są udziałem przede wszystkim mniejszych ugrupowań. Platforma Obywatelska, druga co do wielkości partia, otrzymuje tylko 1 mandat więcej. Natomiast wyraźne zyski odnotowują Nowoczesna i PSL, a nieco mniejsze ruch Kukiz'15. Większe niż w 2011 r. straty zwycięzcy wynikają z tego, że PO w tamtych wyborach była po części poszkodowana na skutek zróżnicowanej frekwencji w okręgach wyborczych. Zastosowane w tym systemie rozliczenie w województwach niweluje częściowo te straty. Zatem nawet jeśli system zmniejsza zyski zwycięzcy z powodu przeliczenia mandatów, to akurat w przypadku Platformy Obywatelskiej w roku 2011 było to częściowo rekompensowane przez zyski związane ze zniwelowaniem różnic w frekwencji pomiędzy okręgami.

System „badeński” znów daje wyniki nieomal identyczne jak w przypadku obecnego systemu. Pomimo stosunkowo małych okręgów zwycięstwa w okręgach jednomandatowych nie generują nagrody większej niż ta, którą już obecnie zapewnia system d'Hondta.

Wariant „węgierski” zwiększa nagrodę dla zwycięskiego Prawa i Sprawiedliwości o 22 mandaty. Odbywa się to z kolei kosztem przede wszystkim Platformy Obywatelskiej, która traci 16 mandatów oraz ruchu Kukiz’15, który zdobyłby o 9 mandatów mniej. Jednocześnie 1 dodatkowy mandat zyskuje Nowoczesna, a 3 mandaty PSL. Widać zatem, że zastosowana w tym modelu metoda kompensacyjna przede wszystkim przesuwa równowagę pomiędzy dwiema głównymi partiami. Z kolei dla najmniejszych partii może być bardziej korzystna niż obecny system.

Nie ma za to wątpliwości, że przeliczenie głosów w systemie „rosyjskim” daje już bardzo znaczącą nagrodę zwycięzcy. 287 mandatów - czyli ponad 50 mandatów dodatkowych - zdobywa przy zastosowaniu tego rozwiązania Prawo i Sprawiedliwość. Wszystkie pozostałe partie dostają mniej mandatów, przy czym największe straty są udziałem ruchu Kukiz'15, który otrzymuje ich nieomal o połowę mniej. Niemniej wszystkie partie otrzymują jakieś mandaty.

Tabela 4. Poziom dysproporcjonalności i efektywna liczba partii parlamentarnych dla prawdziwych i symulowanych wyników wyborów w 2015 r.

\begin{tabular}{|c|c|c|}
\hline Typ systemu & Gh & ENP \\
\hline obecny & 12,56 & 2,75 \\
\hline niemiecki & 10,21 & 3,08 \\
\hline
\end{tabular}




\begin{tabular}{|c|c|c|}
\hline Typ systemu & Gh & ENP \\
\hline badeński & 12,35 & 2,77 \\
\hline węgierski & 14,81 & 2,54 \\
\hline rosyjski & 19,50 & 2,14 \\
\hline
\end{tabular}

Objaśnienia: Gh - wskaźnik dysproporcjonalności (Gallagher, 1991); ENP- efektywna liczba partii parlamentarnych (Laakso, Taagepera, 1979).

Źródło: opracowanie własne.

Ostatnim testem efektów politycznych zastosowania któregoś z wariantów systemu mieszanego w Polsce jest próba oszacowania wyników wyborów w 2019 r. na podstawie uśrednienia wyników wyborów z 2015 i 2011 r. W przypadku ugrupowań, które startowały zarówno w jednych, jak i w drugich wyborach, zachowując swoją tożsamość, było to proste uśrednienie ich wyników na poziomie każdej z jednostek. Działo się tak w przypadku Platformy Obywatelskiej, Prawa i Sprawiedliwości, Polskiego Stronnictwa Ludowego i Sojuszu Lewicy Demokratycznej (którego wynik z 2011 r. uśredniono z wynikiem Zjednoczonej Lewicy w 2015 r.). W przypadku Ruchu Kukiz'15, wynik uśredniono z wynikiem ugrupowania Polska Jest Najważniejsza, w przypadku partii Nowoczesna z wynikiem Ruchu Palikota z 2011 r. Poza takim uśrednieniem dokonano jeszcze jednej korekty, biorąc pod uwagę powyborcze sondaże i zjawiska, stanowiące pewien generalny trend w ogólnoświatowych podziałach politycznych - czyli to, że jeśli słabnie najsilniejsze ugrupowanie, to głosy rozpraszają się pomiędzy pozostałe partie. Skorygowano wyniki Platformy Obywatelskiej i Nowoczesnej w taki sposób, że od wyniku PO w każdym z okręgów odjęto tyle głosów, ile w takim przeliczeniu zdobywa Nowoczesna, natomiast wynik Nowoczesnej podwojono. Oznacza to przesunięcie sił pomiędzy tymi partiami. Jest to zatem jeden $\mathrm{z}$ bardziej optymistycznych z punktu widzenia PiS scenariuszy - dwa główne ugrupowania opozycyjne dzielą się głosami możliwie równo. Ogólnie jednak jest to scenariusz, w którym w kolejnych wyborach nie miałaby miejsca taka polaryzacja, jaką widać było do tej pory, z wyłonieniem wyraźnego zwycięzcy, ale sytuacja, w której największe ugrupowanie ma niższe oparcie, niż to miało miejsce w ostatnich trzech kadencjach.

Najmniejsze zmiany mają miejsce w przypadku zastosowania systemu „niemieckiego”. Odbywają się one w znanym już kierunku, czyli większe ugrupowania tracą mandaty, a zyskują je mniejsze partie. Przede wszystkim na takim rozwiązaniu zyskuje Ruch Kukiza, który otrzymuje ponad trzykrotnie więcej mandatów 


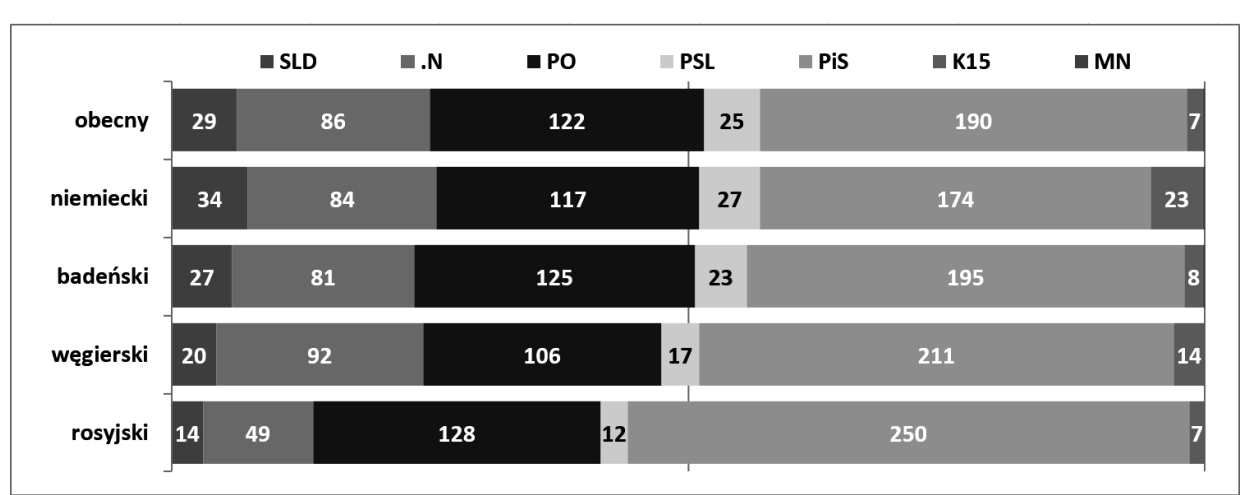

Wykres 3. Porównanie podziału mandatów pomiędzy obecnym systemem a symulowanymi wariantami systemów mieszanych na podstawie symulacji głosowania w 2019 r.

Źródło: opracowanie własne.

niż przy obecnym systemie. Partia o poparciu na poziomie niewiele większym niż $5 \%$ napotyka w dzisiejszym systemie na barierę naturalnych progów wyborczych w większości okręgów - szczególnie jeśli jest partią o wyrównanym poparciu.

Przy takim poziomie politycznego rozdrobnienia system „badeński” natrafia w kilku okręgach na problem dodatkowych mandatów, które zwycięzca otrzymuje dzięki okręgom jednomandatowym, choć nie przysługiwałyby one partii przy proporcjonalnym podziale mandatów. Ich ogólny bilans nie jest jednak znaczący - różnica względem obecnego systemu wynosi 5 mandatów na korzyść PiS i 3 mandaty na korzyść PO.

W przypadku systemu „węgierskiego” sytuacja wygląda już inaczej. Prawo i Sprawiedliwość, jako zwycięzca wyborów, dostaje dodatkowo 21 mandatów przede wszystkim kosztem drugiego ugrupowania, czyli Platformy Obywatelskiej. Na takim rozwiązaniu zyskuje jeszcze Nowoczesna i Ruch Kukiz'15, traci zaś PSL i Lewica. Jak widać, system „węgierski” daje zupełnie inne wzory relacji pomiędzy dużymi i małymi partiami niż obecny polski system wyborczy. Taki wynik dawałaby nadzieję PiS na stworzenie koalicji zwycięskiego ugrupowania z ruchem Kukiza i PSL. Z kolei w rękach PSL pozostaje to, czy będzie on tworzył koalicję z największą partią i ruchem Kukiza, czy też wolałby porozumienie $\mathrm{z}$ trzema partiami po drugiej stronie głównej osi sporu politycznego.

Z kolei w systemie „rosyjskim”, Prawo i Sprawiedliwość zdobyłoby samodzielną większość i 250 mandatów. Wszystkie pozostałe partie zachowałyby reprezentację $\mathrm{w}$ parlamencie, przy czym małe ugrupowania dostałyby wyraźnie 
mniej mandatów. Szczególnie duże straty poniosłaby tutaj Nowoczesna, zaś Platforma Obywatelska zyskałaby, jako to ugrupowanie, które jest w stanie wygrać w istotnej liczbie okręgów jednomandatowych.

Tabela 5. Poziom dysproporcjonalności i efektywna liczba partii parlamentarnych dla symulowanych wyników wyborów w 2019 r.

\begin{tabular}{|c|c|c|}
\hline Typ systemu & Gh & ENP \\
\hline obecny & 7,25 & 3,53 \\
\hline niemiecki & 4,37 & 3,96 \\
\hline badeński & 8,00 & 3,44 \\
\hline węgierski & 9,84 & 3,25 \\
\hline rosyjski & 16,85 & 2,59 \\
\hline
\end{tabular}

Objaśnienia: Gh - wskaźnik dysproporcjonalności (Gallagher, 1991); ENP- efektywna liczba partii parlamentarnych (Laakso, Taagepera, 1979).

Źródło: opracowanie własne.

\section{WNIOSKI}

Na podstawie przeprowadzonych symulacji można zauważyć, że ogólny kierunek działania hipotetycznej ordynacji mieszanej w Polsce byłby zbieżny z efektami generowanymi przez prawdziwe mieszane systemy wyborcze stosowane na świecie. Wariant „niemiecki” daje zgodnie z przewidywaniami wysoki poziom proporcjonalności wyników wyborów. Jego wynik jest najwyższy spośród wszystkich testowanych - również w porównaniu do poziomu proporcjonalności obecnego systemu wyborczego do Sejmu RP - i za wyjątkiem wyborów z 2015 r. (nieproporcjonalnych z powodu nieprzekroczenia przez koalicję Zjednoczonej Lewicy podwyższonej klauzuli zaporowej) zawsze niższy od 5\%, co w literaturze przedmiotu często przyjmuje się jako górną granicę proporcjonalności wyborów (por. Michalak, 2013, s. 298-300). Jest to zgodne z uśrednionymi wartościami, jakie notują mieszane systemy proporcjonalne (por. tabela 2). Symulacje dla systemu „badeńskiego” pokazują, że samo „zmieszanie” systemu może nie mieć istotnego wpływu na wynik wyborów, gdy są one pod wpływem innych jego parametrów - w tym przypadku podziału na okręgi wielomandatowe o średniej wielkości. Jego zastosowanie może nie zmieniać niczego w relacjach między- 
partyjnych w porównaniu z obecnym systemem, co wszakże nie znaczy, że nie uległyby zmianie reguły życia politycznego wewnątrz partii.

Systemy „węgierski” i „rosyjski” są z kolei zdecydowanie nieproporcjonalne. Ten drugi zawsze przekracza wartość $\mathrm{Gh}=10 \%$, podobnie jak ma to miejsce w państwach stosujących systemy paralelne, choć czyni to znacznie wyraźniej niż średnia empiryczna. Z kolei wariant „węgierski” plasuje się pomiędzy systemem „niemieckim” $i$ „rosyjskim”. Z jednej strony jest to zgodne z ich korekcyjną naturą. $\mathrm{Z}$ drugiej zaś nie do końca zgodne $\mathrm{z}$ uśrednionymi wynikami dla tego typu systemów. Na to drugie mają jednak wpływ przede wszystkim różnice techniczne pomiędzy tymi systemami, które w tej grupie mają zdecydowanie największy wpływ na ich ostateczne efekty. Widać to bardzo dobrze na przykładzie kolejnych elekcji na Węgrzech, gdzie występowały bardzo duże wahania dysproporcjonalności. Czyni to tę kategorię najbardziej wrażliwą na błąd nieuprawnionego porównywania. To, co jest jednak najistotniejsze, to fakt, że proponowane w tym artykule zmodyfikowane rozwiązanie „węgierskie” doskonale wpisuje się w cel polityczny stawiany tego typu systemom, a polegający na faktycznym kompensowaniu deformacyjnych właściwości subsystemu większościowego za pomocą mechanizmu transferu głosów. Pod tym względem proponowane i analizowane rozwiązanie jest nawet bardziej wzorcowe i godne naśladowania niż istniejące systemy, które na skutek często sprzecznych wewnętrznie rozwiązań technicznych nie realizują należycie przypisanego do ich istoty celu kompensacyjnego.

Analogicznie wygląda kwestia koncentracji systemu partyjnego. Indeks efektywnej liczby partii parlamentarnych - zgodnie z oczekiwaniami formułowanymi na podstawie uśrednionych wyników istniejących systemów mieszanych najwyższe (wyższe nawet niż w obecnym systemie) wartości zanotował (powyżej 3) przy zastosowaniu mieszanego systemu proporcjonalnego. Z kolei największa koncentracja wystąpiła (ENP > 2) przy zastosowaniu modelu „rosyjskiego”. Ponownie wariant korekcyjny okazał się rozwiązaniem pośrednim. Z kolei kombinowany system „badeński” jest nieomal tożsamy w efektach z obecnym systemem wyborczym. Notabene choć obecna ordynacja jest oparta na formule proporcjonalnej (proporcjonalna „na wejściu”), to w swoich efektach przekracza - nawet istotnie - wyznaczane w literaturze przedmiotu granice dopuszczalnych 5\% odchyleń od proporcjonalności przewidywanych dla tej grupy (nie jest wystarczająco proporcjonalna „na wyjściu”).

Jak widać, każdy z tych systemów inaczej rozstrzyga problem relacji pomiędzy nagrodą dla zwycięskiego ugrupowania a reprezentacją elektoratów mniejszych partii. Wydaje się, że obecny polski system wyborczy znajduje się gdzieś pomię- 
dzy tymi biegunami. Tworzy on wyraźny bonus dla zwycięzcy, w porównaniu z systemami o wysokiej proporcjonalności (jak w systemie niemieckim), ale nie jest to na pewno taka nagroda, jaką zapewnia system „węgierski” czy „rosyjski”. Taka nagroda jest do odtworzenia przez system mieszany, jeśli jest przy proporcjonalnym podziale mandatów skonfigurowany możliwie blisko obecnego polskiego systemu.

Zestawiając ze sobą wszystkie rozwiązania, można powiedzieć, że system korekcyjny w proponowanym tutaj kształcie premiowałby zwycięzców elekcji bardziej niż obecna ordynacja, choć w przypadku mniejszych partii byłby w efektach stosunkowo bliski dotychczasowym rozwiązaniom. System paralelny w wariancie „rosyjskim” wygenerowałby w konsekwencji silnie dysproporcjonalny i skoncentrowany system dwu-i-półpartyjny z dużą premią dającą zawsze zwycięzcy większość bezwzględną mandatów. Z kolei model „niemiecki” sprzyjałby efektywnie ponadtrzypartyjnej rywalizacji w bardzo proporcjonalnych warunkach. W tym wachlarzu możliwości jest też jednak miejsce i dla takiego systemu, który zachowuje dotychczasowe mechanizmy polskiej ordynacji w relacjach między partiami, ograniczając swoje oddziaływanie do relacji wewnątrzpartyjnych. Te jednak nie były przedmiotem przedstawianych analiz, choć pozostają $\mathrm{w}$ obszarze zainteresowań autorów i będą tematem kolejnych opracowań.

\section{Bibliografia:}

Álvarez-Rivera, M. (2009). Election Resources on the Internet: Elections to the Hungarian National Assembly. Pobrane z: http://www.electionresources.org/hu/.

Blais, A., \& Massicotte, L. (1996). Mixed electoral systems: An overview. Representation, 33(4), 115-118. Pobrane z: https://doi.org/10.1080/00344899608522970.

Bormann, N.-C., Golder, M. (2013). Democratic Electoral Systems around the world, 1946-2011. Electoral Studies, 32(2), 360-369. Pobrane z: https://doi.org/10.1016/j. electstud.2013.01.005.

Colomer, J.M. (2004). The handbook of electoral system choice. Basingstoke: Palgrave Macmillan.

Farrell, D.M. (2001). Electoral Systems: A Comparative Introduction (1 edition). Houndmills-Basingstoke-Hampshire, New York: Palgrave Macmillan.

Farrell, D.M. (2011). Electoral Systems: A Comparative Introduction (2 edition). Houndmills-Basingstoke-Hampshire, New York: Palgrave Macmillan.

Ferrara, F., Herron, E.S., \& Nishikawa, M. (2005). Mixed electoral systems: contamination and its consequences (1 edition). New York: Palgrave Macmillan.

Flis, J. (2014). Zludzenia wyboru: społeczne wyobrażenia $i$ instytucjonalne ramy w wyborach do sejmu i senatu. Kraków: Wydawnictwo Uniwersytetu Jagiellońskiego. 
Gallagher, M. (1991). Proportionality, disproportionality and electoral systems. Electoral Studies, 10(1), 33-51. Pobrane z: https://doi.org/10.1016/0261-3794(91)90004-C.

Gallagher, M., Mitchell, P. (red.). (2005). The Politics of Electoral Systems. Oxford: Oxford University Press. Pobrano z http://www.oxfordscholarship.com/view/10.1093/019 9257566.001.0001/acprof-9780199257560.

Gschwend, T., van der Kolk, H. (2006). Split Ticket Voting in Mixed Member Proportional Systems: The Hypothetical Case of The Netherlands. Acta Politica, 41(2), $163-179$.

Haman, J. (2003). Demokracja. Decyzje. Wybory. Warszawa: Wydawnictwo Naukowe Scholar.

Kamiński, M.M. (2016). Ordynacje większościowe i JOW-y. Warszawa: Wydawnictwo Naukowe „Scholar”.

Laakso, M., Taagepera, R. (1979). "Effective” Number of Parties: A Measure with Application to West Europe. Comparative Political Studies, 12(1), 3-27.

Lakeman, E., Lambert, J.D. (1955). Voting in democracies: a study of majority and proportional electoral systems. London: Faber \& Faber.

Massicotte, L., Blais, A. (1999). Mixed electoral systems: a conceptual and empirical survey. Electoral Studies, 18(3), 341-366. Pobrane z: https://doi.org/10.1016/ S0261-3794(98)00063-8.

Mayorga, R.A. (2001). Electoral Reform in Bolivia: Origins of the Mixed-Member Proportional System - Oxford Scholarship. W: M.S. Shugart \& M.P. Wattenberg (red.), Mixed-Member Electoral Systems: The Best of Both Worlds? (s. 194-208). Oxford: Oxford University Press.

Michalak, B. (2013). Mieszane systemy wyborcze. Cele, rozwiązania, konsekwencje. Toruń: Wydawnictwo Naukowe Uniwersytetu Mikołaja Kopernika.

Michalak, B. (2016). Czy duże okręgi wyborcze zawsze zwiększają proporcjonalność wyborów? Nowe dowody z polskich wyborów parlamentarnych. Decyzje, (25), 67-82. Pobrane z: https://doi.org/10.7206/DEC.1733-0092.71.

Moser, R.G., Thames, F.C. (2001). Compromise Amidst Political Conflict: The Origins of Russia's Mixed-Member System. W: M.S. Shugart, M.P. Wattenberg (red.), Mixed-Member Electoral Systems: The Best of Both Worlds? (s. 255-275). Oxford: Oxford University Press.

Nohlen, D. (2004). Prawo wyborcze i system partyjny: o teorii systemów wyborczych. Warszawa: Wydawnictwo Naukowe Scholar.

Norris, P. (1997). Choosing Electoral Systems: Proportional, Majoritarian and Mixed Systems. International Political Science Review, 18(3), 297-312. https://doi. org/10.1177/019251297018003005.

Raciborski, J. (2006). Teoria demokracji a reguły wyborów. Nauka, (3), 27-44.

Reynolds, A., Reilly, B., Ellis, A. (2005). Electoral System Design: The New International IDEA Handbook. Stockholm: International IDEA.

Sartori, G. (1997). Comparative Constitutional Engineering: An Inquiry Into Structures, Incentives, and Outcomes (2 Edition). New York: New York University Press. 
Scheble, Q.B. (red.). (2015). Welcome to the State Parliament. Landtag von Baden-Württemberg. Stuttgart: The President of the State Parliament of Baden-Württemberg.

Schoen, H. (1999). Split-ticket voting in German Federal elections, 1953-90: an example of sophisticated balloting? Electoral Studies, 18(4), 473-496. Pobrane z: https://doi. org/10.1016/S0261-3794(99)00023-2.

Shugart, M.S., Wattenberg, M.P. (red.).(2001). Mixed-member electoral systems: the best of both worlds? Oxford-New York: Oxford University Press.

Sokół, W. (2007). Geneza i ewolucja systemów wyborczych w państwach Europy środkowej i wschodniej. Lublin: Wydawnictwo Uniwersytetu Marii Curie-Skłodowskiej.

Taagepera, R. (2007). Predicting Party Sizes: The Logic of Simple Electoral Systems. Oxford: Oxford University Press. 